\title{
PORTUGAL'S MASCULINITIES CRISIS: GENDER EQUALITY IN THE ERA OF FLAGGING ECONOMIES
}

\begin{abstract}
Europe's financial crisis has precipitated the implementation of adjustment programs, led by a «Troika» of global institutions (European Union, International Monetary Fund, the European Central Bank). A disruption of the economic environment is taking place, with serious effects on social and family cohesion. The fast impoverishment of already vulnerable populations has led to an increase in social inequalities, while shifting relations between men and women in public and private spaces. The ramifications of the European crisis are not entirely detectable yet. Using existing literature and data from Portugal, this article attempts to bridge this gap by understanding the impact of the economic crisis on masculinities and gender relations.
\end{abstract}

Keywords: masculinities, gender, financial crisis, austerity, domestic violence.

\section{Resumo}

\section{A Crise de Masculinidades em Portugal}

A crise financeira na Europa tem precipitado a implementação dos programas de ajustamento estrutural, liderados por uma «Troika» de instituições (União Europeia, Fundo Monetário Internacional, o Banco Central Europeu). A destruição da vida económica está em curso, com repercussões na coesão social e familiar. O empobrecimento de populações vulneráveis tem como resultado tanto o aumento de desigualdades sociais como uma mudança nas relações entre homens e mulheres.. As ramificações da crise europeia não são ainda inteiramente detectáveis. Usando literatura existente e dados de Portugal, o presente artigo tenta colmatar esta lacuna através da análise do impacto da crise económica sobre masculinidades e relações de gênero.

Palavras-chave: masculinidades, gênero, crise financeira, austeridade, violência doméstica.

\section{Résumé}

La crise des Masculinités du Portugal

La «Troïka» composée par l'Union Européenne, le Fond Monétaire International et la Banque Centrale Européenne, est à l'origine des programmes d'ajustements structurels amenés par la crise financière Européenne. Ces programmes ont créé une instabilité économique et ont des répercussions sur le tissu social et familial. L'appauvrissement de ces populations vulnérables, creuse des inégalités sociales croissantes, tout en modifiant les relations hommes femmes dans les espaces publics et prives. Les conséquences de la crise Européenne ne sont pas complètement dévoilées. Utilisant la littérature existante et des données du Portugal, cet article afin de comprendre l'impact de la crise économique sur les masculinités et les relations de genre.

Mots-clés: masculinités, sexe, crise financière, l'austérité, violence domestique. 


\section{Gender and masculinities in the context of the European economic crisis}

In Portugal, as in Southern Europe, the impact of the financial and economic crisis has resulted in rising unemployment, reduced household incomes and dwindling social protection nets. Despite the fact that some governmental voices have started to state that the financial and economic crisis is 'over', it continues to affect many households and families in Southern Europe. One glance at recent media headlines and emerging research shows that the crisis continues to have an impact on all aspects of daily life in Portugal. These include plummeting family incomes either due to unemployment, salary or benefit cuts; increases in depression and other mental health illnesses as a result of economic stresses; increases in domestic violence cases; accumulation of household debt; and the plight of unemployed youth back to already indebted family households (UN, 2013). In the context of so many changes, it is not surprising that the economic crisis and responding austerity measures have severely disrupted household and family relations across Southern Europe.

The market and economic crisis has impacted not only family life, but has redefined social and economic relationships between men and women. Research shows that financial crises have a differential impact on women and men, given their differential positions and power relations within economic and social spheres (EC, 2012b). In addition, these gendered impacts may differ depending on the social status and class of men and women (e.g. immigrant men and women, working class men and women, men and women in rural versus urban areas). Some policy measures have been implemented at the Portuguese and EU levels to tackle the causes of the crisis on the financial level and address its economic and social impacts (e.g. the European Economic Recovery Plan in 2008). However, in the urgency of the crisis it appears that, to date, little attention has been given to ensuring that gender is fully mainstreamed or taken into account in policy responses (EC, 2012b). Under this scenario, perspectives regarding men and masculinities have often been dismissed as less important - ignoring the premise that gender is relational, or that is, gender is constructed from relations between men and women, and their interactions with other social structures and realities.

This article examines men and masculinities within the context of the current economic crisis for three main reasons: (1) to understand how the European crisis has impacted gender relations and challenged social norms related to masculinities and being a man; (2) then using the Portuguese example, identify what consequences such challenges have on masculinities and gender in/equality, and; (3) provide guidance, including the need for preventive and gender mainstreaming policy responses, in reducing potential long term impacts of the economic crisis on social and family life. To assess the impact of Europe's financial crisis on masculinities and gender relations, a desk review methodology was employed, reviewing extensive literature from Portugal, Europe and the global south. The 
search resulted in the review of 46 primary and secondary documents, including primary data on employment and socio-economic indicators, in addition to published studies on gender norms and the effects of the economic crisis on masculinities and gender relations in Europe.

\section{How economic crises challenge ideas of masculinities and gender relations}

As has been seen in the economies of developing countries that have grappled with recession, the most vulnerable populations are the first to fall victims to social and economic crisis. Existing literature affirms that social vulnerability defined as the increased probability and risk of being exposed or experiencing an episode of poverty over time - clearly increases in times of crisis (UN, 2013). For instance, unemployment, salary cuts and loss of income can all increase the likelihood of household poverty. Research shows that economic crises appear to affect different social groups, but in particular already vulnerable groups ranging from poorer, immigrant, youth, single parents, to elderly populations (Whelan and Maître, 2005).

There is extensive literature that women are one of the most at risk groups in a period of rising state-sector cutbacks and unemployment. They are a group with a tendency to be employed in fragile, non-permanent contracts, and as a result, are more vulnerable during recessions (EC, 2012b). In particular, the reduction of arrangements to reconcile work and family life exacerbates the «double burden» of paid and unpaid work (Aboim and Vasconcelos, 2012). Accordingly, women are also more vulnerable to discrimination in access to jobs, education, health and political representation. This has an immediate effect on household income, but a much longer-term effect on the role of women in the labour force. Additional adverse effects include lower average incomes and primary responsibility for care work in the household. In this scenario, austerity measures such as wage and pension cuts increase women's already vulnerable position in the labour market, increasing the gender pay gap and their burden of caregiving at home.

Much less is known about the impact of such financial crisis on gender relations and in particular, how such crises challenge ideas and norms of masculinity and femininity. Existing research and theoretical framing affirm that masculinities: (1) are complex and heterogeneous, rather than singular, and that factors such as age, education, employment, marital and socioeconomic status, nationality, ethnicity and religion must be taken into account; (2) are part of a relational notion of gender in which they are not isolated from, but rather interact with, femininities and the gender order; and (3) are fluid, dynamic and changing over time and context (Connell, 2005).

Constructions and identities of masculinities are therefore complex. Masculinities are constructed from a number of socio-demographic factors; they are 
relational to gender and femininities; and are dynamic and fluid as per the social context at hand. In light of this complexity, Europe's economic crisis has posed challenges to social constructions and ideas of masculinities. The most evident and visible impact has been the large loss of men's jobs in the construction and manufacturing sectors, which have been most affected by the crisis (EC, 2013a). A number of studies show that male workers in Europe have been far worse affected by job cuts and layoffs, namely in the Baltic countries, Ireland and Spain (Vaughn-Whitehead, 2012).

The loss of employment or income, coupled with household economic stress and uncertainty, challenge traditional norms of masculinities. In particular, such economic stresses can challenge norms around positioning the man as the «breadwinner,» and as having a central role in the household economy. Having difficulties in providing material resources and income for the household can therefore represent a degradation of power and loss of identity. Unsurprisingly, this can impact men's self-confidence, mental health, and stress coping mechanisms. For instance, studies show that men cope more detrimentally than women with job loss and displacement (Aboim and Vasconcelos, 2012). Suicide and alcohol abuse are also examples of men's negative coping (EC, 2012a). Studies have also found clear linkages between men's economic stress and their use of violence against female partners and children's exposure to this violence (ICRW and Promundo, 2011) - which, in turn, point to the need for further research on connections between domestic and inter-family violence, and violence in public/urban spaces.

As a result, 'violent masculinities' are prone to emerge and take root, especially when men and families have limited access and control of financial resources. When in vulnerable or underemployed jobs, men, who are socially expected to perform this role, may suffer from not being able to live up to this expectation, feeling unable to fulfill what they perceive to be their mission within their households and society (Barker et al., 2011). As such, men and boys feel increasingly lost and powerless when facing increasing economic stress, as they are both unable to provide the basic needs for their families and are unsure about the future. Within this context, violence can erupt as a way to regain the power perceived as lost. As discussed earlier, men who experience economic or workrelated stress are more likely to report depression, thoughts of suicide, and use of violence (Moller-Leimkuhler, 2003), precisely due to dominant conceptions of masculinity and definitions associated with being a man. Pleck (1995) has referred to this as "gender role strain", in the sense that men face emotional and mental stress when they are not able to live up to this provider role.

Dominant masculinities share a particular conception of the male figure and hence, of manhood - as always independent, leading, authority-driven, risktaking, aggressive, heterosexual, rational, absent regarding emotions and providing for the household, to which images of femininity and other masculinities are marginalised and subordinated (Wall, Aboim and Cunha, 2010). A number of 
surveys suggest (ICRW and Promundo, 2011) that many men, informed by this traditional concept of dominant masculinities, believe that they have the right to be violent toward women or men in order to prove their power and masculinity. Often, guns and other weapons are a symbol of this dominant and violent masculine code that is shared across class boundaries, and that legitimises and normalises violence as an instrument for obtaining and defending power (Connell, 2005).

A major gap in the gender literature is how boys are socialised into men young men's construction of masculinities - and especially how these constructions are challenged during times of crisis. These constructions are met with expectations to provide for the family (with enhanced pressures in times of economic strain); and often, the option to use violence as a tool to achieve status, exert power or control that is threatened or lost, and to achieve social belonging. Yet crises shape, but do not predetermine, young men's responses; some men follow trajectories or use violence in various forms, others respond in alternative and positive ways.

The promotion of non-violent and caregiving forms of masculinities are essential in avoiding negative effects of economic crisis among households and the overall economy. As resources become scarcer during economic downturn, relations among household members become strained, and the social fabric is often torn as heads of households abandon the family and rates of domestic and community violence increase. At home and globally, women and girls are performing the bulk of care work for children and other dependents (Budlender, 2008). According to MenCare's State of the World's Fathers, time spent on domestic chores and care activities is still gender-divided, and it varies worldwide and even among the different European countries (2015). For instance, data shows that in Italy, women typically spend 162 more minutes per day than men on routine housework; while in Spain and Sweden, women on average spend 51 and 16 more minutes per day than men on house chores, respectively (Levtov et al., 2015). Within this context, inter-generationally passed down norms influence men's practice on a wide range of issues, including leaving the bulk of divisions of labour and caregiving at home to women (Kimmel, 2000).

Norms around parental caregiving are particularly affected in times of crisis. As mentioned earlier, women's loss of employment can increase their burden of care work at home and have long-term effects on the labour force participation of women. Unfortunately, most European policies often neglect unpaid work, where the imbalance in gender roles is even greater than in childcare, despite clear, though insufficient, steps towards that end. At the same time, there is clear evidence that having children lower women's earnings and increase the gender pay gap. For instance, a recent study showed that mothers tend to earn less than women without any children in $60 \%$ of 22 developed countries studied (Levtov et al., 2015). In Portugal, women with no children earn 3 times more than mothers with at least one child (Levtov et al., 2015). In fact, care as a concept has been 
very simplistically perceived and comprehended both analytically and politically, mainly as far as masculinities are concerned. This bias is even more present during economic crisis and austerity measures, where social and gender-mainstreamed policies, such as increased parental leave for both mothers and fathers, are often not prioritised. Across a number of studies conducted in the European Union, fathers commonly cited insufficient compensation as a reason for not taking leave (Levtov et al., 2015). Since men typically earn more than women, taking an uncompensated paternity leave is interpreted as a risk for fathers and a higher loss in total family income (Levtov et al., 2015). Yet, feminist literature (Apparala, Reifiman and Munsch, 2003) asserts that promoting men's caregiving brings both men and women better satisfaction with life, relationship fulfilment, and general well being. There is increasing acceptance of these feminist standpoints, with a number of policies in Europe now focusing on supporting male involvement in active fatherhood. In this regard, research (EC, 2013) has also shown that structural variation (e.g. duration of paternity leave) is of key importance concerning men's decisions around engaging in care.

\section{The impact of the Portuguese financial crisis on masculinities and gender equality}

In Portugal, like the rest of Europe, the economic crisis is having a strong impact on unemployment, social safety nets and gender inequality. The initial government responses (2007-2009) were characterised by unprecedented counter-cyclical fiscal and monetary policies aimed at guaranteeing social protection while stimulating economic demand to prevent a full-blown global depression. However, since 2010, many governments have focused on austerity policies as emergency measures, often sidestepping regular channels of participation and accepted democratic checks and balances. European and international institutions of economic governance have also assumed a central role in enforcing austerity. Many of these austerity measures - characterised by public expenditure cuts, regressive tax hikes, reduced labour protection and pension reforms - have exacerbated the already severe social consequences of the economic crisis marked by record levels of unemployment. As will be discussed below, such austerity measures have only served to increase the gender pay gap and reinforce women's traditional roles as caregivers at home.

The socio-economic repercussions and numbers of the financial crisis in Portugal are jarring. In the last four years, 298,000 people have lost their jobs (INE, 2015), in addition to thousands of others who have lost their savings and homes. During the second trimester of 2015, the national employment rate stood at $11.9 \%$ with a total of 620,400 unemployed individuals (INE, 2015). At the same time, social protection safety nets were reduced as a result of the austerity measures, reducing the amount and length that those unemployed could receive unemployment benefits. Despite some signs of economic recovery, Portugal has 
done little to address issues of poverty and social exclusion. Since 2010, more than 210,000 individuals in Portugal have been at the margins of poverty and social exclusion (INE, 2015). As a result, such high levels of unemployment, inadequate housing, along with skyrocketing prices, and failure in providing financial security and basic needs to one's own household, have placed many families under severe stress.

One key repercussion of the financial crises has been the shift in masculinised and feminised forms of Portuguese employment and unemployment. Portugal traditionally has a dual earner family model, with high rates of working Portuguese women, as a result of social policies in the 2000s promoting equal access to employment and social rights and benefits (Ferreira, 2013). Data from the 2010 European Social Survey shows that in Portugal, 62.4\% of Portuguese couples between the ages of 18 to 65 years old, had both women and men working actively outside the home. In the latter half of the 2000s, a number of policies were also introduced aimed at promoting men to become more engaged in childcare, including increased parental leave and other types of support for family life (Ferreira, 2013).

Portuguese women have traditionally been more affected by unemployment than men, but since 2009 data shows that men in fact have been most affected (INE, 2012). This is largely due to the fact that most jobs have been lost in the manufacturing and construction industries where men make up the majority of the work force. From 2009 to 2011 for instance, men had lost 222,600 jobs compared to 138,200 jobs that had been lost by women (Ferreira, 2013: 213). Between 2008 and 2011, two out of three salaried jobs were also lost by men (Ferreira, 2013: 213). For men in particular, more flexible types of employment such as part-time and temporary jobs soared. From 2009 to 2012, net job gains in parttime jobs increased by $36.6 \%$ among men, while women experienced net losses in the same sector by $-3.0 \%$ (Ferreira, 2013: 218).

This trend points to an interesting phenomenon - the masculinisation of flexible and part-time work and visible under-employment of men (Ferreira, 2013) - and a consequent gender shift in occupational roles. These economic shifts have had psychological consequences on families. A 2014 study conducted by the World Health Organization (WHO) and the European Observatory on Health Systems and Policies showed that the financial crisis and austerity measures in Portugal led to increases in depression and other mental health cases among the general population (Sakellarides, Castelo-Branco, Barbosa and Azevedo, 2014). There have also been notable increases in youth violence and domestic violence. For instance, juvenile delinquency among youth between 12 and 16 years old increased by 453 cases or 23.4\%, from 2013 to 2014 (Sistema de Segurança Interna, 2014: 118). In addition, 31 more cases of domestic violence were recorded from 2013 to 2014 (Sistema de Segurança Interna, 2014: 18), leading the Secretary General of Internal Security, Helena Fazenda, to call the need for larger attention in addressing the issue. 
As a result, one consequence of the economic crisis has been an increase in domestic violence cases. Men's difficulties in fulfilling gender and social expectations of being «breadwinners» at home have been associated to a growth of cases of domestic violence in the country. Overall, Portugal has the largest number of femicides (gender-related murders) in the European Union. However, recent data shows that gender violence increased in recent years (mainly in the domestic context). In 2013, 27,318 complaints were registered in police and judicial offices (Report of the Ministry of Home Affairs). That same year, a reported 37 women had been killed as a result of domestic violence; at the end of 2014, 43 such cases were reported (UMAR, 2014: 4). Of these 43 women, 35 died at the hands of their husbands or partners, and the remaining 8 at the hand of another family member (father, uncle or father-in-law; UMAR, 2014:4). Although there exists a gap in formalised research between the relationship of the economic crisis and escalations in domestic violence, there are a growing number of linkages being evidenced. The commissioner for Human Rights of the Council of Europe expressed concern over the stress that economic situations are having on families and the risk of domestic violence, for both women and children, which may have even more severe impacts in the long term.

Another key impact of the economic crisis has been the reinforcement of traditional roles of men and women at home. A number of employment sectors traditionally held by women also suffered heavy losses, affecting women's financial autonomy and caregiving roles at home. Women primarily lost jobs in more independent and informal categories such as self-employment jobs (Ferreira, 2013). From 2008 to 2010 for instance, the self-employed sector had net job losses of $13.1 \%$ among women, compared to just a 5.4\% drop among men (Ferreira, 2013: 213). In particular, the fiscal austerity policies led to large employment cuts and hiring freezes in the public administration sector, an area of large employment for women. At the same time, a recent study stressed the importance of the public sector for women's financial empowerment. The study findings showed that women's income autonomy in dual earner households not only typically increased with higher levels of education, but also among those who are employed in the public sector (Ferreira, 2013: 223). This would indicate that women's job losses in the public sector could be potentially placing women back to their traditional roles at home, decreasing their financial autonomy and increasing their share and burden of domestic work. As well, according to INE (2012), women were the main actors in caregiving to elders and dependents, which show that despite being emancipated in the public sphere, women remain subordinated in the private domain. Unfortunately, such austerity cuts in the public administration sector may not only reduce overall household income, but increase women's burden of care at home, hereby affecting women's economic autonomy and gender inequality outcomes in Portugal (Ferreira, 2013).

The impact of the financial crisis is two-fold, both challenging and reinforcing traditional norms of masculinities and femininities among Portuguese society. 
First, social norms around dominant masculinities are being challenged due to rising male unemployment, especially as men are being forced to question and rethink their roles as «breadwinners.» On the other hand, austerity cuts, and in particular within the public sector, are undermining and reinforcing women's traditional roles as caregivers at home, having a much longer-term effect on the role of women in the labour force.

The Portuguese case demonstrates that the context of economic crisis may have produced changes in the traditional roles performed by men and women. Intimate relations are thus marked by an apparent relocation of men within the standards of hegemonic masculinity, a situation that can potentially lead to conflicts and violence in the private sphere (Wall, Aboim and Cunha, 2010). However, the full extent of these gendered aspects of the crisis are still unknown and more research is needed to explore the relationship between masculinities during times of financial crisis and impacts such as domestic violence. What we do know, however, is that issues such as domestic violence have long-term, intergenerational consequences that can be prevented. For instance, an analysis of Promundo's International Men and Gender Equality Survey (IMAGES) findings from six countries showed that adults who engaged in violent behaviour as adults had also experienced or witnessed violence as children (ICRW and Instituto Promundo, 2011). These shifts point to the increasing need for both research and preventive programs that can help men and women in Portuguese society question social norms and expectations around gender roles, hereby preparing women, men and families in coping with economic crises and stressors.

\section{Discussion for Future Research and Policies}

The first step in bridging gender inequalities and addressing family crises is understanding how men and women react to and cope with economic stress and changes in family's structures and values. This also includes understanding which everyday tactics and strategies allow for the construction of more equitable and caring versions of masculinity. To question dominant masculinities, as well as to draw an analytical distinction between hegemonic masculinities and subordinate, hyper-masculinities and non-violent masculinities, can help us capture the power inequalities which exist among men, as well as between men and women. Furthermore, strategies that can promote gender-equality and positive masculinities must be based on men's and women's diverse experiences and perceptions.

Our approach views gender equality as a greater public good with benefits and implications for all, which becomes even more crucial to understand and promote during a moment of social and economic crisis. The prevailing view of gender being synonymous with women can be seen as a way of perpetuating current power imbalances. In this prevailing view, «gender» is translated as compensatory policies that «help» women rather than policies that transform the 
power structures that perpetuate gender inequality. While women's rights and equality have been on the agenda in Europe for a long time, the integration of men's experiences and perspectives have been marginal. This is surprising, given the new evidence that men's participation in caregiving and household tasks has a strong impact on gender equality and crisis prevention. For instance, the results from Promundo's IMAGES and a number of studies highlighted in the State of the World's Father report show that men who are more involved as fathers feel more satisfied with their lives, take better care of their health, and carry out a more equitable share of the care work (Barker et al., 2011). In fact, during the last decade, there has been an increasing acknowledgement of the crucial role of men in building gender equality as equal partners with women. Consequentially, men have increasingly become subjects of studies and part of gender equality policies in the EU, as the 2013 European Commission (EC) study on The Role of Men in Gender Equality - European Strategies and Insights demonstrates.

At the same time, social and economic policies during crisis recovery make little mention of «gender», «equality,» «women» and even less about «men» and «masculinities» (see for example the European Economic Recovery Plan 2008). This absence is indicative of the limited inclusion of a gender lens, let alone gender mainstreaming, in responses to the crisis (EC, 2012b) and pushes us to seek new gender equality policy responses. In addition, while Europe has advanced protection and justice-sector approaches to violence against women, primary prevention is generally lacking. For instance, limited research has looked at the factors associated with men's use of intimate partner violence in Europe from a cross-cultural perspective and in times of economic crisis.

Promoting policies around parental leave can be one key vehicle in transforming gender roles and norms around caring masculinities and fatherhood. As of 2013 however, paternity leave provisions could only be found in the national legislations of only 78 out of 167 countries (47\%) with many offering between just 1 and 6 days (Levtov et al., 2015). The notion around men's share of care and caring masculinities encompass wider psychological, social and cultural changes that are vital to understand for post-crisis European development. In this context, the promotion of caregiving can actually be tapped as a way to promote greater resilience:

- As more fathers become involved in care and housework, the higher the economic emancipation of women;

- As more fathers become involved in caregiving for their children, the better the maternal and child health outcomes;

- The earlier and more active fathers become in children's lives, the better the child development outcomes;

- The higher men's involvement in children care, the lower rates of violence against women and children, and;

- As more men participate in caregiving, the higher improvements to men's physical and mental health. 
Many of these lessons and «how-to's» can be learned from the Latin American context, where countries have grappled resiliently since the 1980s with financial crises, structural adjustment programs, austerity measures, in addition to income and gender inequalities. One noteworthy campaign is Instituto Promundo «Você é meu Pai» advocacy campaign, the Brazilian arm of the global MenCare campaign. The campaign aims to mobilise attention around men's participation in domestic work, maternal health and caregiving, all of which have been traditionally ignored in Latin American gender equity discussions. The campaign is active in increasing visibility on paternal policies including fathers' paternity leave after birth, in addition to disseminating key messages aiming at transforming men's participation in non-violent caregiving. This year, Promundo, the MenCare and «Você é meu Pai» campaigns released the State of Brazil's Fathers report (A Situação da Paternidade e Cuidado no Brasil), following the State of the World's Fathers report, increasing visibility around evidence on fatherhood and caregiving, existing and needed legislation around parental leave and men's health in Brazil. Finally, another key initiative includes Program P (P for paternidade/paternidad, 'fatherhood' in Portuguese and Spanish, respectively) developed in response to Promundo's IMAGES - which revealed that active fatherhood could serve as an effective conduit to promote gender equity and prevent gender based violence. In 2013, the Program P manual was piloted in Brazil, Guatemala, Indonesia, Nicaragua, Rwanda and South Africa in partnership with health care systems to train health care workers in engaging fathers and couples during prenatal visits in preparation for their roles as future parents.

In Europe, a better understanding of men in caregiving roles requires looking into some of the «best practices» in terms of European and international policies that promote equal sharing. This is clearly illustrated by looking at how countries can benefit from the best models of paternity leave policies, and how these can positively influence social inclusion and employment options for both men and women. Norway, along with other Scandinavian countries and the UK, has started the first wave of policies toward equal parental leave, with strong incentives to break the traditional gender divide. However, these policies have not - outside of those few countries - been taken up across the rest of Europe (EC, 2013). And, while such policies increased men's participation in care work, the gap in pay between women and men remains, and men's share of care work continues to lag behind women's share, especially in those countries without any parental leave measures.

All of these examples highlight the importance of understanding men's caregiving roles and practices, and highlight why understanding masculinities in times of crisis is key to revising and implementing policies to promote gender equality in care work, particularly in times of widening economic inequality. Future research should seek to explore the extent to which men have been actively involved in providing and/or receiving care for children, elders and friends in times of financial and social crises as to; a) assess the needs, expecta- 
tions and resources related to such care provision; b) examine policies regarding caregiving, suggesting ways to improve such policies; c) contribute to theoretical debates on care, and masculinity studies, and; d) evaluate the impact of such policies on improved family wellbeing and overall economy, including reduction of domestic violence and increases in women's financial autonomy.

\section{Final Remarks}

Economic stress, changes in the labour market and social change in Europe have affected women and men in different ways. There are two key assumptions. First, crises present different challenges to 'everyday politics' as traditionally understood. They are fertile ground for the rupture and/or transformation of social contracts and societal structures, norms and dynamics, including relationships among women, men, peers and family members. The current crisis in Europe present the continent and its countries with challenges, or better yet, a number of opportunities for catalysing political and social mind-set change. Second, gender equality is central to social solidarity, and therefore it should be a fundamental dimension of Europe's social and political foundation. That said, little research has looked at how definitions of manhood - whether violent, conservative and inequitable or non-violent, caring and equitable, - are understood, constructed and affected in the context of the current crisis.

Although we cannot expect to find a clear connection between economic growth and all of the aspects of gender equality, we cannot deny that there is a connection between gender equality, policy action, economic and welfare growth and employment - achieved through employment factors, such as activity rates, unemployment rates and gender segregation indicators. The financial crisis and its effects have never been gender-neutral, even if the repercussions may sometimes balance themselves out (e.g. women and men losing different types of jobs). In other words, there are specific masculinised reactions to the crisis and masculinised forms of financial risk-taking that minimise or downplay the importance of social wellbeing.

Understanding men's fluid attitudes and practices related to care and domestic violence, when responding to intensified economic, social and political crisis, is thus essential in informing more effective social responses in times of crisis. Increasingly, policymakers are beginning to understand how men's lives are shaped by gendered norms and realities, and how men's attitudes and practices related to women are also key for achieving gender equality. One promising area of research includes the promotion of men's share of work in caregiving and parental leave, particularly in times of financial crises. As discussed, studies (Barker and Pawlak, 2011) affirm that women's income and equality generally increase with greater participation by men in unpaid care work. Furthermore, research also reaffirms that relatively small reforms such as parental leave can 
have long-term effects, leading to a more gender-balanced household work division and advancements in women's professional autonomy (Brandth and Kvande, 2004). However, more research is needed to help understand the array of factors, including economic stressors and crisis that often drive the use of violence and lead to absent caregiving. What seems clear from the last decade of European and global research is that understanding men's roles and realities is vital for achieving economic and social development, and even more so in times of crisis recovery.

\section{References}

Aboim, Sofia; Vasconcelos, Pedro (2012), Study on the Role of Men and Gender Equality in Portugal, Instituto de Ciências Sociais da Universidade de Lisboa (ICS), Brussels, European Union Programme for Employment and Social Solidarity - PROGRESS (2007-2013).

Apparala, Malathi; Reifiman, Alan; Munsch, Joyce (2003) Cross-national Comparison of Attitudes toward Fathers and Mothers' participation in Household Tasks and Childcare, Sex Roles 15, 189-204.

Barker, Gary; Pawlak, Peter (2011), Men, Families, Gender Equality and Care Work, in United Nations (org.) Men in Families and Family Policy in a Changing World, Department of Economic and Social Affairs, Division for Social Policy and Development, New York, United Nations, 9-45.

Barker, Gary et al. (2011), Evolving Men: Initial Results from the International Men and Gender Equality Survey (IMAGES) Washington DC, International Center for Research on Women (ICRW) and Rio de Janeiro, Instituto Promundo.

Budlender, Debbie (2008), The Statistical Evidence on Care and Non-Care Work across Six Countries, Geneve, United Nations Research Institute for Social Development.

Brandth, Berit; Kvande, Elin (2004), Paternity Leave and Work-family Reconciliation in a Flexible Working Live, Working Paper, Trondheim, NTNU.

Connell, Raewyn (2005), Masculinities, 2nd edition, Sydney, Allen \& Unwin.

European Commission (EC) (2012a), Eurobarometer 78 - Public opinion in the European Union, [online] available at http://ec.europa.eu/public_opinion/archives/eb/ eb78/eb78_first_en.pdf [retrieved on 12/03/2015].

European Commission (EC) (2012b), The Impact of the Economic Crisis on the Situation of Women and Men and on Gender Equality Policies: Synthesis Repor, Luxembourg, Publications Office of the European Union.

European Commission (EC) (2013), The Role of Men in Gender Equality - European Strategies and Insight», [online] available at http://ec.europa.eu/justice/genderequality/files/gender pay gap/130424 final report role of men en.pdf [retrieved on 12/04/2015].

Ferreira, Virgínia (2013), Employment and Austerity: Changing welfare and gender regimes in Portugal, in Maria Karamessini; Jill Rubery (org.), Women and Austerity: The economic crisis and the future for gender equality, London and New York, Routledge, 207-227.

ICRW and Promundo (2011), Evolving Men: Initial Results from the International Men and Gender Equality Survey (IMAGES), Men+ Gender Equality Policy Project 28(7), 1269-83. 
Instituto Nacional de Estatística (2015), Estatísticas do Emprego, $2^{\circ}$ semestre de 2015, 5 de agosto de 2015, Lisboa, INE, 1-13.

Instituto Nacional de Estatística (2012), Estatísticas no Feminino: Ser Mulher em Portugal, 2001-2011, Lisboa, INE, 1-31.

Kimmel, Michael (2000), The Gendered Society, New York, Oxford University Press.

Levtov, Rut et al. (2015), State of the World's Fathers: A MenCare Advocacy Publication, Washington, DC, Promundo, Rutgers, Save the Children, Sonke Gender Justice, and the MenEngage Alliance.

Moller-Leimkuhler, Anne Maria (2003), The Gender Gap in Suicide and Premature Death or: Why are Men so Vulnerable?, Eur Arch Psychiatry Clin Neurosci 253(1), 1-8.

Pleck, Joseph (1995), The Gender Role Strain Paradigm: An Update, in Ronald F. Levant and William S. Pollack (eds.) New Psychology of Men, New York, Basic, 11-32.

Sistema de Segurança Interna (2014), Relatório Anual de Segurança Interna - Ano 2014, Lisboa, Gabinete do Secretário-Geral, 1-482.

Sakellarides, Constantino; Castelo-Branco, Luís; Barbosa, Patrícia; Azevedo, Helda (2014) The Impact of the Financial Crisis on the Health System and Health in Portugal, Denmark, World Health Organization, 1-56.

União de Mulheres Alternativa e Resposta [UMAR] (2014), OMA - Observatório de Mulheres Assassinadas da UMAR: Dados 2014, Lisboa, UMAR, 1-53.

UN (2013), World Economic Situation and Prospects, [online] available at http:// www.un.org/en/development/desa/policy/wesp/wesp_archive/2013wesp.pdf [retrieved on 15/01/2015].

Vaughn-Whitehead, Daniel (ed.), (2012) Work Inequalities in the Crisis: Evidence from Europe, Geneva, Edward Elgar Publishing, 600+.

Wall, Karin; Aboim, Sofia; Cunha, Vanessa (2010), A Vida Familiar no Masculino: Negociando Velhas e Novas Masculinidade, Estudos 6, Lisboa, Comissão para a Igualdade no Trabalho e Emprego (CITE).

Whelan, Christopher; Maître, Bertrand (2005), Vulnerability and Multiple Deprivation Perspectives on Economic Exclusion in Europe; A latent class analysis», European Societies, 7(3), 423-450.

Tatiana Moura. Executive Director of Instituto Promundo (Rio de Janeiro, Brazil), an international NGO that works to engage men and boys for gender equality. She is also a researcher at CES since 2000 and holds a PhD in Peace, Conflicts and Democracy, by the University Jaume I (Spain). t.moura@promundo.org.br

Esther Spindler. Consultant with Instituto Promundo. She holds a M.S. in Development Management, by the School of International Service at American University. spinej17@gmail.com

Alice Taylor. Consultant with Instituto Promundo. She holds a master's in International Affairs from the Fletcher School at Tufts University.

a.taylor@promundo.org.br

Instituto Promundo, Rua da Lapa 161, Centro, Rio de Janeiro, RJ, 20021-180, Brazil

Artigo recebido em 17 de julho de 2015 e aceite para publicação em 23 de outubro de 2015. 